\title{
The perspectives of Translation studies
}

\author{
S. Gokhila ${ }^{1}$, Dr. V. Thiyagarajan ${ }^{2}$ \\ ${ }^{1}$ Department of English, Anna University of Technology, Coimbatore, India \\ ${ }^{2}$ Department of English,Bannari Amman Institute of Technology, Sathyamangalam, India
}

\begin{abstract}
This article discuses about importance of translation, methods of translation, problems of translation like culture based problems, dialectal problems, and kinship word problems.

This article is focused on the issues of literary translation and non-literary translation from source language text to the target language text. The general aspects of the same are being highlighted in this article. This article also centres about the decisive factors needed for both translations. It also spotlights the differences between literary and non-literary translation. This article lucidly explains the basic need of a literary and non literary translator.
\end{abstract}

Keywords: Literary translation, non- literary translation, source language text, target language text, literary translator, non-literary translator.

\section{Introduction}

"Nothing can progress without translation" E.S Bates Nida says, "Successful translation involves one of the most complex intellectual challenges known to mankind; moreover, in our present communication between those using different languages gives the translator a position of new and strategic importance". Translation is an important tool for the development and growth of a language. The first and fore most thing in translation studies is the transfer of meaning from one language to another. Translation is being done by the people who wish to make his mother language fertile. Translation needs constant decision making. It is an activity comprising the interpretation of the meaning of a text in one language the source language and the other language the target language.

Translation has accelerated inter-linguistic communication between people. Theoretically one considers it as science but practically it seems rational to consider as an art. Good translation should fulfil the same function in the TL as original in the SL. If translation be an art, it is not easy one. The translator should know both languages the SL language and the TL language. This is because languages are not just different words. Different languages also have different grammar, different word orders, sometimes even they have words for which other languages do not have any equivalents. The English spoken by a scientist may have words, which a simple farmer cannot even start to imagine. Moreover, the farmer is likely to have words for things the technologist never dreamed of. Nida defines translation as, "Essentially the translation process is one in which a person who knows both the source and receptor language, decodes the message of the source language and encodes it into an appropriate equivalent from the receptor language".

\section{Methods of Translation}

There are some methods of translation. They are minimal translation method, literal translation method, lexical synonymy, and paraphrase. In general translation is done by three methods (i) word-for-word (ii) different words for a single word (iii) extend and explain SL words.

\subsection{Minimal Translation}

When translators find difficulty in translating certain English words to Tamil they just transliterate into Tamil and so naturally those words get used or accustomed to the public, as the result people use those words in the day to day life automaticall

\subsection{Literal Translation}

In this method the structure of sentence is given more importance than the meaning and so translators find the job to be a difficult thing to translate a whole sentence or a paragraph. Only a word can be translated in this method. Naturally this method cannot be applied to all kinds of translation.

\subsection{Lexical Synonymy}

In this method the translators use related words in translation process. They feel tough to translate some of the words from SL to TL in such case they use related words to translate. 


\subsection{Paraphrase}

Grasping the meaning of SL text and explaining it by replacing the equivalent ideas. Most of the translators adopt this method.

\section{Culture Based Problems in Translation}

From a particular translated work of art the readers can understand the bliss and sufferings of the native people. The TL readers can also understand about the culture followed by a particular group of people. Through the translated works even common people can know about the culture, behaviour, sufferings, gender harassment of other natives. Culture is the way of living of a particular sector of people. 'Cultural language' is to be distinguished from 'universal language' and 'personal languages'. Universal words such as 'breakfast', 'embrace', and 'pile', often cover the universal function but not the cultural description. 'thali', 'kunggumam', 'chittappa', 'valaikappu', 'metti' these are all culture based words. These above SL words cannot be translated by replacing the exact TL words.

The culture based problems arise mainly due to the cultural gap or distance between the SL and TL. There is generally a translation problem while translating the social language what is called idiolect. Most 'cultural' words are easy to detect. Since they are associated with a particular language and cannot be literally translated. When cultural customs are taken into account they are described in ordinary language. Since literal translation would distort the meaning, translation may need an appropriate descriptive functional equivalent.

\section{Dialect and Dialectal Problems in Translation}

Dialect is a form of language which is spoken in a particular part of a country and contains some different words, grammar and pronunciation from other forms of the same language. No language is monolithic in character; there are varieties within each language. No single language is absolutely superior or inferior to another language in any grounds. Some particular features of one language may differ from other language. There are varieties classified on the basis of users of a particular language these varieties may be called dialects with in a language. There are two sub- varieties of dialects.

(a) Varieties according to region, such as Tirunelveli Tamil, Kanyakumari Tamil, Chennai Tamil, Kovai Tamil, in the SL text and English such as British English, American English or Australian English.

(b) Varieties according to education and social standing (ie) the language used by the upper class people, the language used by the working classes and elite people. According to the community the varieties differ in SL text Tamil but regarding social status. This is not the case with TL English there is no such varieties prevail like in SL, Tamil.

Regional dialects and class or social dialects belong to above varieties (a) and (b) respectively. Cockney being the variety of English it is used by the poorer working classes of London; it is both a regional and a class dialect. In a language dialectal differences manifest themselves at three levels (a) phonology or pronunciation (b) lexis or vocabulary and (c) grammar which include both morphology and syntax. The translators have to select an equivalent target language dialect when a text passages is a dialect other than the unmarked dialect, and this is common in literary works, particularly in the dialogue of novels and plays.

Catford says, "Dialect themselves also present translation problems. Many languages, as Catford points out, have a 'standard' or literary dialect which shows only slight variation from one to another and over long stretches of time. For translation purposes it may be regarded as unmarked and an unmarked text in the unmarked dialect of the source language can usually be translated into an equivalent unmarked target language dialect. If there is no such dialect the translator may have the exciting task of helping to create a new literary dialect of the TL or resort to other expedients."

According to Catford all the varieties of a language have common features like grammatical, lexical and phonological forms. In addition to these every variety has some, peculiar features which are called the 'makers' of the variety. Unlike in English and French it is very hard to find an equivalent variety in the SL and TL are not genetically related. When a translator consider the above points, the translator can resort to Catford's strategy; many languages have a 'standard' or 'literary' dialect which shows little variation in its written form at least from one locality to another. When such a dialect 'unmarked' is regarded is convenient, particularly in connection with translation.

\section{Distinction in the Kinship terms}

If the speaker of the SL passage is addressing the lady of her neighbouring house as 'mami' or as 'mama'. The use of the kinship term 'mami' or 'mama' is not necessarily used only among the relatives. In the TL also, such reference among non-relatives exist and so the SL term 'mami' or 'mama' has been translated as 'aunty' or 'uncle' respectively in its informal reference. Such non-linguistic societal customs should be taken into consideration by the translator. In the SL, the kinship term like 'cittappa' is referred using only the TL 
kinship term 'uncle'. Some sector people address other ladies as 'mami' even though they are not relatives. Likewise the SL terms like 'attai', 'mami', 'citti' have only one referent in the TL, ie., aunt.

Table 1

\begin{tabular}{|c|c|c|c|c|c|}
\hline \multirow[t]{2}{*}{ English } & \multicolumn{2}{|l|}{ Lineal } & \multicolumn{2}{|l|}{ Colineal } & ablineal \\
\hline & masculine & feminine & masculine & feminine & \multirow{6}{*}{ cousin } \\
\hline $\begin{array}{l}\text { Second } \\
\text { generation } \\
\text { previous }\end{array}$ & grand father & grand mother & Uncle & aunt & \\
\hline $\begin{array}{l}\text { previous } \\
\text { generation }\end{array}$ & father & mother & & & \\
\hline $\begin{array}{l}\text { same } \\
\text { generation }\end{array}$ & \multicolumn{2}{|l|}{ ego } & Brother & sister & \\
\hline $\begin{array}{l}\text { next } \\
\text { generation }\end{array}$ & son & daughter & & & \\
\hline $\begin{array}{l}\text { second } \\
\text { generation } \\
\text { following }\end{array}$ & grand son & grand daugher & nephew & niece & \\
\hline
\end{tabular}

Table 2

\begin{tabular}{|c|c|c|c|c|c|}
\hline \multirow{2}{*}{ Tamil } & \multicolumn{2}{|l|}{ lineal } & \multicolumn{2}{|l|}{ colineal } & \multirow{2}{*}{ ablineal } \\
\hline & masculine & faminine & masculine & feminine & \\
\hline $\begin{array}{l}\text { second } \\
\text { generation } \\
\text { previous }\end{array}$ & tatta & patti & \multirow{2}{*}{$\begin{array}{l}\text { mama } \\
\text { cittappa } \\
\text { periyappa }\end{array}$} & \multirow{2}{*}{$\begin{array}{l}\text { attai } \\
\text { citti } \\
\text { periyamma }\end{array}$} & \multirow{6}{*}{$\begin{array}{l}\text { maittunan } \\
\text { maittuni }\end{array}$} \\
\hline $\begin{array}{l}\text { previous } \\
\text { generation }\end{array}$ & appa & amma & & & \\
\hline \multirow[t]{2}{*}{ same generation } & & & cakotaran & cakotari & \\
\hline & & & annan tampi & akka tankai & \\
\hline next generation & makan & makal & marumakan & marumakal & \\
\hline $\begin{array}{l}\text { second } \\
\text { generation } \\
\text { following }\end{array}$ & peran & petti & & & \\
\hline
\end{tabular}

From the Table 1 and 2, one can know the differences between the SL and TL kinship terminology. The translator should consider carefully the referent in the non-linguistic world. The translator should avoid translating simply as literal translation and should see to that the particular person referred to.

\section{Literary Translation}

The "Prison of language is only temporary......... someday a merciful guard? The perfect translator will come along with his key and let us out," Wendy Lesser wrote in an article. Antone Berman says, "The great split that divided the entire field of translation separation so-called "Literary" translations (in broad sense) "nonliterary" translations (technical, scientific, advertising etc)". "All acts of communication are acts of translation" George Steiner. The goal of literary translation aims for publication. It may be said to have greatest number of peculiar problems and these problems largely depend on who is translating and what the translator knows. "Translation is like a woman if beautiful, it cannot be faithful and if faithful, it cannot be beautiful". J.C. Catford defines translation from the linguistic point of view. He says that translation is "the replacement of textual material in one language by the equivalent material in another language". Translation has been described differently as an 'art', a 'craft', a 'science' by Theodore Savory, Eric Jacobson and Eugene Nida respectively. None of the above is adequate because it is more than all. Translation is a process of analysis, interpretation, and creation. It leads to a replacement of one set of linguistic resources and values for another.

Creativity and translation are inseparable, especially in literary rendition. Literary translation needs innovative thinking while translating the 'formalities' of the source language text. Translating literary works is always challenging and controversial due to aesthetic and expressive values such as figurative languages, metaphors and differences in cultural and historical contexts. Delicate emotional connections between cultures and languages are linked by literary translation. Nature and the style of the source language and target language are interdependent in literary translation. In this literary translation the translator has to do the translation with the at most care. Literary translation gives importance to linguistic, stylistic and semantic of source language. 
Literary translation has the powerful contextual influence on translation. The translation of a poem, a novel, a short story or a play is different in the field of literary translation. Since one to one translation normally represents collocation meanings, literary translation goes beyond one-to-one translation. This translation ranges from one word to one word, through group to group, collocation to collocation, clause to clause, sentence to sentence. Even though literal translation appears tedious there is satisfaction when weighing it.

Translators share a number of problems irrespective of the text they translate some of the problems which are specific to literary translation and therefore need to be discussed separately. One can agree that literary translation is 'an original subjective activity at the centre of a complex net work of social and cultural practices'. Even though literary translation is being done the lingering doubt is prevailing that if the translation is done to the fullest? This is the reason why when attempting to translate a technical text, the translator has to begin by making sure that he understands the source text terminology very well and the translator should also know the precise equivalent in target text. As a specialist in the field, the translator may be already familiar with the relevant terminology in both languages. Careful search in specialised dictionaries and glossaries can also give a good result. In literary translation the attention is just not only on the context but also on the manner in which that particular content has been expressed. Literary translation implies the translation of all genres of literature, which include prose, drama and poetry. Johnson (1999: 1) describes literature as 'an apparently nebulous body of knowledge in oral or written form, an imitation of life, which reflects civilization and culture and which covers every angle of human activities culture, tradition entertainment, information among others.'

Literary translation has to do with translating texts written in a literary language is distinct from the language of science or that of administration. This literary language is highly connotative and subjective because each literary author is lexically and stylistically idiosyncratic and through his power of imagination, he uses certain literary techniques such as figures of speech, proverbs and homonyms through which he weaves literary forms.

A literary translator is a person who translates literary texts. A literary translator, according to Peter Newmark (1988:1) generally respects good writing by taking into account the language, structures, and content, whatever the nature of the text. The literary translator finds oneness with the author's creative activity and then recreates structures and signs by adapting the target language text to be source language text as closely as he can do. The literary translator needs to assess not only the literary quality of the text but also its acceptability to the target reader and this should be done by having a deep knowledge of the cultural and literary history of the source and target language. Greatest number of peculiar problems that the literary translations have largely depended on who is translating and what the translator knows. The problem of literary translation includes cultural, linguistic, psychological deceptive cognates, equivalence and style.

Language and culture are closely related and one is indispensable to the other in fact language acquires its meaning from the country's culture. A single language may cross several borders. For instance, English and French are Indo- European languages but belong to different cultures. There are generally problems in the translation of cultural words in literary text unless there is a cultural overlap between the source languages and the target language. The important motive of the translator is that, it is not for he himself knows what words are used in the target language; he must also make the TL reader to understand the real meaning as it is understood by the SL reader. The translator is sure to get the translation problem while translating the culture based words; it is due to the cultural gap between the source and the target language.

The literary translator also faces the problem of style. It is not an easy term to define, however, it can readily be said that style is a how one says a thing. Style is the way in which something is written or said, as distinct from its subject matter. The goal of literary translation is publication. Translating for pleasure or as intellectual exercise is well and good, but the dedicated literary translator aims at sharing final result with target language readers. Of all forms that translation such as commercial, financial, technical, scientific, advertising etc, only literary translation lets one consistently share in the creative process. In this translation alone does the translator experience the aesthetic joys of working with great literature, of recreating a new language?

\section{Non-literary Translation}

Non-literary ones belong to the world of facts. They are about objects, but both literary and non-literary texts are concerned with the fundamental truths of translation. No profession is as divided as that of translation. Non literary texts consist of knowledge, facts and ideas, information and reality. These kinds have clarity of information. Non- literary texts tend to allow the reader to simply enjoy the texts. Rather than having an intension to teach a person something. It is easy to translate. Sole purpose of literary text is for entertainment, it also usually lack in metaphor and symbols. There is no need to reread any of the text, because there are no layers of complication rather it means what it says. To be simple and frank non- literary texts are more than mindless babble, it lacks in substance to be thought in a classroom so there won't be any difficulty while translating. 
Non-literary text stays simple and lacks in complicated lessons, the purpose of texts is given less important, but these text are books that are more popular and easier to read. Non- literary prose is informational writing, full of facts so there will not be any imagination. For example informational explanations, text books, news paper, articles, journals and diary entries etc.

The language consists of signs and they have a pattern and structure of their own. The language which is a part and parcel of human society has signs which differ from one language another. As Edward Sapir affirms that, 'no two languages are ever sufficiently similar to be considered as representing the same social reality. The worlds in which different societies live are distinct worlds, not merely the same world with different labels attached.' It is clear that from the beginning of life on earth, there has been a basic need for translation, when literary and non-literary translation is considered.

\section{Conclusion}

Translation is the mode of communication. In a nation unity can be achieved through translation. This is most applicable to a nation like India where we have 1652 spoken languages 40 nationalized languages and only 18 official languages. The interaction between languages will enrich the literature and culture of a land. The needs, interests and attractions will vary from man to man. Translation helps in the overall growth of human life. Mans nature is to adapt himself to all that is beautiful, potential, powerful and profitable this is made possible only through translation. At present the scope, range, quality and significance of translation are felt at wide range. The work of translation in the field of communication is responsible for the spread of news. AlanDuff rightly points out the importance of translation in the modern world, in the following worlds: without translators 'there would be no summit talks, no glasnost or Perestroika, no Cannes film festival, no Noble prizes, no advances in medicine, science or engineering, no international law, no Olympic games, no Hamlet, no war and peace.' Translation has become an independent discipline in academic circles because the importance of translation is realised greatly at present days. The love and peace will be prevailed if the classics in all the languages are translated and read.

\section{Reference}

[1] Alan Duff, Translation (Oxford: Oxford university Press), 1989

[2] Baker, mona (1992) In other words: a Course book on Translation, London: Routledge.

[3] Bassnett, Susan. (1991), Translation Studies.

[4] Catford, John C. (1965) A Linguistic Theory of Translation: An Essay on Applied Linguistics London: Oxford University Press:

[5] Landers E, Lirerary Translation: a Practical guide by Clifford.

[6] Maria T. Scanchez: The Problems of Literary Translation: a study of the theory and practice of translation from English to Spanish.

[7] Nida, Eugene A. (1964) Towards a Science of Translating Leiden: E.J. Brill.

[8] Site: $\underline{\text { www.article }}$ on line directory. com 